\title{
HUBUNGAN TINGKAT STRES TERHADAP DISMENORE PADA REMAJA PUTRI DI MADRASAH ALIYAH MAMBA'UL ULUM AWANG-AWANG MOJOSARI MOJOKERTO
}

\author{
Sari Priyanti. ${ }^{1}$, Anggraeni Devi Mustikasari. ${ }^{2}$ \\ ${ }^{1}$ Dosen Politeknik Kesehatan Majapahit \\ ${ }^{2}$ Mahasiswa Politeknik Kesehatan Majapahit
}

\begin{abstract}
The rate occurance dysmenorrhea in Indonesia is estimated with $55 \%$ of women childbearing age tormented with pain during menstruation. One of factors causes dysmenorrhea is psychological. One of them is stress. The purpose of this study is to determine the relationship of stress to occurance dysmenorrhea during menstruation in adolescent girls.This research used cross sectional study. The independent variable is the level of stress and the dependent variable is dysmenorrhea in adolescent girls. The population in this study is 46 respondents. The technique is probability sampling with simple random sampling. The data are collected with a questionnaire of stress scale and occurance dysmenorrhea. The data are processed by editing, coding, scoring, tabulating. The results show that almost half of respondents who do not stress or normal consists of 18 respondents ( $39.1 \%$ ) and the majority of respondents who experience dysmenorrhea amount 29 respondents ( $63.0 \%$ ). Base on statistic test conclude that there is a correlation between the level of stress and dysmenorrhea in adolescent girls in Mamba'ul Ulum Madrasah Aliyah Awang-Awang Mojosari Mojokerto. The school should to give counseling teachers to provide guidance and counseling to the students in order to anticipate and overcome stress.
\end{abstract}

\section{A. PENDAHULUAN}

Dismenore adalah penyakit nyeri uteri pada saat menstruasi. Dismenore primer tidak dikaitkan dengan patologi pelvis dan bisa timbul tanpa penyakit organik (Baradero, 2007). Hampir semua perempuan mengalami rasa tidak nyaman selama haid, seperti rasa tidak enak di perut bagian bawah dan biasanya juga disertai mual, pusing, bahkan pingsan. Kondisi ini bertambah parah bila disertai dengan kondisi psikis yang tidak stabil, seperti stres, depresi, cemas berlebihan, dan keadaan sedih atau gembira yang berlebihan. Nyeri haid dapat menyerang perempuan yang mengalami haid pada usia berapapun. Tidak ada batasan usia dan sering disertai dengan kondisi-kondisi yang memperberat seperti pusing, berkeringat dingin, bahkan hingga pingsan. Jika sudah seperti ini, tentunya nyeri haid tidak boleh dibiarkan begitu saja. Nyeri haid harus diatasi dengan benar (Anurogo, 2011).

Angka kejadian dismenore di dunia sangat besar. Rata-rata lebih dari 50\% wanita di setiap negara mengalaminya. Di Amerika Serikat angka prosentasenya sekitar $60 \%$ dan di Swedia sekitar $72 \%$. Sementara di Indonesia diperkirakan $55 \%$ wanita usia produktif tersiksa oleh nyeri selama menstruasi. Angka kejadian dismenore tipe primer di Indonesia adalah sekitar 54,89\% sedangkan sisanya adalah tipe sekunder (Proverawati, 2009). Dismenore terjadi pada wanita dengan tingkat stres rendah sebesar $22 \%$, dengan tingkat stres sedang 29\% dan wanita dengan tingkat stres tinggi sebesar 44\% (Noviana, 2008).

Berdasarkan hasil studi pendahuluan pada tanggal 5 maret 2014 kepada 37 siswi MA Mamba'ul Ulum, sebanyak 100\% (37 siswi) mengalami stres dan 75,7\% (28 siswi) yang mengalami dismenore saat menstruasi. Hal ini menunjukkan indikasi adanya kejadian dismenore saat menstruasi. 
Salah satu penyebab dismenore adalah faktor psikis. Salah satu faktor psikis tersebut adalah stres (Wijayanti, 2009). Stres dapat mengganggu kerja sistem endokrin. Sistem endokrin terganggu ketika endometrium dalam fase sekresi memproduksi prostaglandin F2 yang menyebabkan kontraksi otot-otot polos sehingga dapat menyebabkan rasa sakit saat menstruasi atau dismenore (Anurogo, 2011).

Peran tenaga kesehatan dalam menghadapi masalah ini adalah sebagai edukator yang dapat memberikan informasi tentang hubungan stress dengan kejadian dismenore diantaranya yaitu memberikan edukasi mengenai dismenore, penyebab dismenore serta upaya penanganan dismenore melalui penyuluhan atau poster.

Berdasarkan uraian di atas, peneliti tertarik untuk melakukan penelitian mengenai tingkat stres dengan terjadinya dismenore saat menstruasi pada remaja putri di Madrasah Aliyah Mamba'ul Ulum Awang-awang Mojosari kabupaten Mojokerto.

\section{B. TINJAUAN PUSTAKA}

\section{Dismenore.}

a. Pengertian.

Istilah dismenore (dysmenorrhea) berasal dari kata dalam bahasa yunani kuno (Greek) kata tersebut berasal dari dys yang berarti sulit, nyeri, abnormal; meno yang berarti bulan; dan rrhea yang berarti aliran atau arus. Dengan demikian, secara singkat dismenore dapat di definisikan sebagai aliran menstruasi yang sulit atau menstruasi yang mengalami nyeri (Anurogo, 2011).

b. Gejala dismenore berdasarkan klasifikasinya.

Dismenore dibagi menjadi 2 jenis yaitu:

1) Dismenore primer

Orang yang mengalami dismenore primer terlihat gejala-gejala umum seperti rasa tidak enak badan, lelah, mual, muntah, diare, nyeri punggung bawah, sakit kepala, kadang-kadang dapat juga disertai vertigo atau sensasi jatuh, perasaan cemas, gelisah, hingga jatuh pingsan (Anurogo, 2011)

2) Dismenore Sekunder

Nyeri dengan pola yang berbeda didapatkan pada dismenore sekunder yang terbatas pada onset haid. Dismenore terjadi selama siklus pertama atau kedua setelah haid pertama, dismenore dimulai setelah usia 25 tahun.

c. Faktor-faktor yang mempengaruhi Dismenore

Faktor-faktor yang dapat mempengaruhi dismenore menurut Arulkumaran (2006) antara lain:

1) Faktor menstruasi

a) Menarche dini, gadis remaja dengan usia menarche dini insiden dismenorenya lebih tinggi.

b) Masa menstruasi yang panjang, terlihat bahwa perempuan dengan siklus yang panjang mengalami dismenore yang lebih parah.

2) Paritas, insiden dismenore lebih rendah pada wanita multiparitas. Hal ini menunjukkan bahwa insiden dismenore primer menurun setelah pertama kali melahirkan juga akan menurun dalam hal tingkat keparahan.

3) Olahraga, berbagai jenis olahraga dapat mengurangi dismenore. Hal itu juga terlihat bahwa kejadian dismenore pada atlet lebih rendah, kemungkinan karena siklus yang anovulasi. Akan tetapi, bukti untuk penjelasan itu masih kurang.

4) Pemilihan metode kontrasepsi, jika menggunakan kontrasepsi oral sebaiknya dapat menentukan efeknya untuk menghilangkan atau 
memperburuk kondisi. Selain itu, penggunaan jenis kontrasepsi lainnya dapat mempengaruhi nyeri dismenore.

5) Riwayat keluarga, mungkin dapat membantu untuk membedakan endometriosis dengan dismenore primer.

6) Faktor psikologis (stres)

Pada gadis-gadis yang secara emosional tidak stabil, apalagi jika mereka tidak mendapat penjelasan yang baik tentang proses haid, mudah timbul dismenore. Selain itu, stres emosional dan ketegangan yang dihubungkan dengan sekolah atau pekerjaan memperjelas beratnya nyeri.

d. Pencegahan

Pencegahan dismenore menurut Anurogo (2011) adalah

1) Menghindari stres

2) Miliki pola makan yang teratur dengan asupan gizi yang memadai, memenuhi standar 4 sehat 5 sempurna

3) Saat menjelang haid, sebisa mungkin menghindari makanan yang cenderung asam dan pedas

4) Istirahat yang cukup, menjaga kondisi agar tidak terlalu lelah, dan tidak menguras energi secara berlebihan

5) Tidur yang cukup, sesuai standar keperluan masing-masing 6-8 jam sehari Lakukan olahraga ringan secara teratur

e. Pengobatan seperti Pengobatan herbal, Penggunaan suplemen, Perawatan

2. Stres medis, Relaksasi, Hipnoterapi.

\section{a. Pengertian Stres}

Dalam kamus besar Bahasa Indonesia (Balai Pustaka, 2007) yang dimaksud dengan stres adalah gangguan atau kekacauan mental dan emosional yang disebabkan oleh faktor luar atau ketegangan. Stres adalah suatu kondisi atau keadaan tubuh yang terganggu karena tekanan psikologis (Wulandari, 2010).

b. Sumber stres (stressor)

Stressor adalah sumber stres yang dipersepsi seseorang atau sekelompok orang yang memberi tekanan/cekaman terhadap keseimbangan diri mereka.

c. Tingkatan stres

Menurut Stuart dan Laraia (2005), ada 3 macam tingkatan stres antara lain

1) Stres ringan berhubungan dengan ketegangan yang dialami sehari-hari.

2) Stres sedang memungkinkan individu untuk berfokus pada hal-hal yang penting.

3) Stres berat individu cenderung pada suatu objek yang dapat mengurangi ketegangan

\section{d. Gejala stres}

Gejala yang sering ditemukan pada orang yang mengalami stres menurut Hawari (2008) dan Wangsa (2010) adalah:

1) Gejala psikologis : kecemasan, ketegangan, kebingungan dan mudah tersinggung, perasaan frustasi, marah, perasaan terkucil dan terasing, kehilangan konsentrasi, kehilangan kreativitas serta menurunnya rasa percaya diri.

2) Gejala fisiologis : jantung berdebar-debar, muka pucat, gangguan gastrointestinal, gangguan pernafasan, gangguan pada kulit (timbul jerawat, kedua telapak tangan dan kaki berkeringat), sering buang air kecil, mulut dan bibir terasa kering, sakit kepala, sakit pada punggung bagian bawah, ketegangan otot serta gangguan tidur. 
3) Gejala perilaku : menunda dan menghindari pekerjaan, menurunnya prestasi, perilaku makan yang tidak normal yang mengarah ke obesitas dan penurunan berat badan, serta menurunnya kualitas hubungan inter personal dengan keluarga dan teman

\section{METODE PENELITIAN}

\section{Jenis dan Rancang Bangun Penelitian.}

Penelitian ini menggunakan jenis penelitian analitik. Penelitian analitik merupakan suatu penelitian yang mencoba mengetahui mengapa masalah kesehatan tersebut bisa terjadi, kemudian melakukan analisis hubungan antara faktor risiko (faktor yang mempengaruhi efek) dengan faktor efek (faktor yang dipengaruhi oleh risiko) (Riyanto, 2011). Sedangkan desain penelitian yang digunakan adalah cross sectional. Penelitian cross sectional merupakan suatu penelitian yang mempelajari hubungan antara faktor risiko (independen) dengan faktor efek (dependen), dimana melakukan observasi atau pengukuran variabel sekal idan sekaligus pada waktu yang sama (Riyanto, 2011).

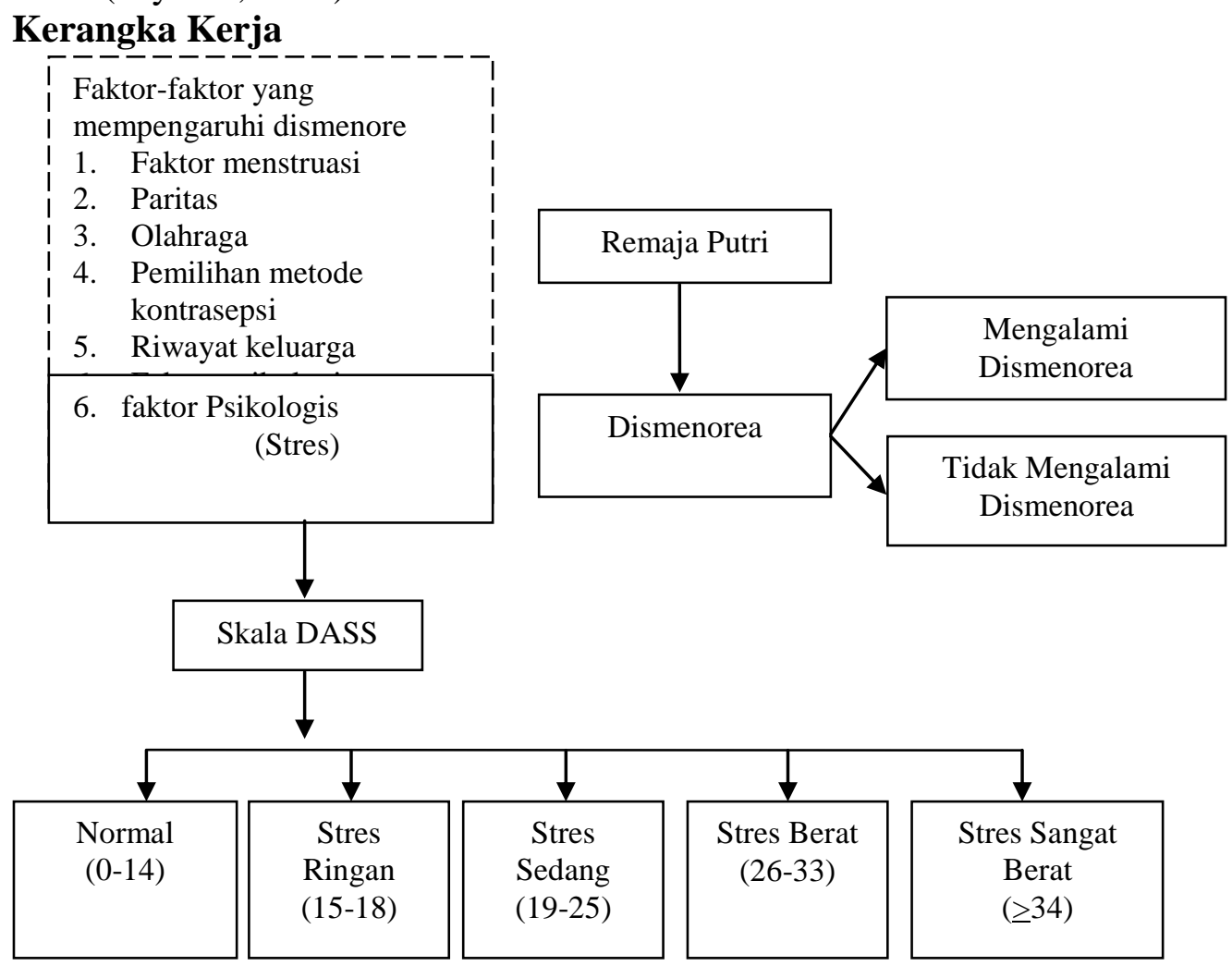

\section{Gambar 1. Kerangka Konsep Hubungan Tingkat Stres Dengan Kejadian} Dismenore

Sumber : Arulkumaran (2006), Nursalam (2013)

Keterangan :

: Variabel yang tidak diteliti

: Variabel yang diteliti

pengaruh. 


\section{Hipotesis Penelitian.}

Variabel Hipotesis berasal dari kata hupo dan thesis, hupo artinya sementara kebenarannya dan thesis artinya pernyataan atau teori. Jadi hipotesis merupakan pernyataan sementara yang perlu di uji kebanarannya. Hipotesis didalam penelitian berarti jawaban sementara penelitian yang kebenarannya akan dibuktikan dalam penelitian (Riyanto, 2011)

Didalam penelitian ini hipotesis yang akan dibuktikan adalah :

$\mathrm{H}_{1}$ : Ada hubungan tingkat stres dengan terjadinya dismenore pada remaja putri.

3. Variabel dan Definisi Operasional.

\section{a. Variabel}

Dalam Dalam penelitian ini digunakan 2 jenis variable, yaitu :

1. Variabel independen/bebas yaitu variabel yang mempengaruhi atau nilainya menentukan variabel lain. Dalam penelitian ini tingkat stres sebagai variable independen.

2. Variabel dependen/terikat yaitu variable yang dipengaruhi nilainya ditentukan oleh variabel lain. Dalam penelitian ini dismenore pada remaja putri sebagai variabel dependen.

\section{b. Definisi Operasional}

Tabel 1 Definisi operasional hubungan tingkat stres dengan terjadinya dismenore pada remaja putri

\begin{tabular}{|c|c|c|c|}
\hline Variabel & Definisi Operasional & Kriteria & Skala \\
\hline $\begin{array}{l}\text { Variabel } \\
\text { independen } \\
\text { Tingkat stres } \\
\text { pada remaja }\end{array}$ & $\begin{array}{l}\text { Respon tubuh yang } \\
\text { dialami remaja terhadap } \\
\text { tuntutan atau beban pada } \\
\text { saat nyeri haid, yang } \\
\text { meliputi : } \\
\text { 1. Gejala psikologis } \\
\text { 2. Gejala fisiologis } \\
\text { 3. Gejala perilaku } \\
\text { Alat ukur kuesioner }\end{array}$ & $\begin{array}{l}\text { 1) Normal : 0-14 } \\
\text { 2) Stres Ringan: } \\
15-18 \\
\text { 3) Stres Sedang : 19-25 } \\
\text { 4) Stres Berat : } \\
\text { 26-33 } \\
\text { 5) Stres Sangat Berat }: \geq 34 \\
\text { (Nursalam, 2013) }\end{array}$ & Ordinal \\
\hline $\begin{array}{l}\text { Variabel } \\
\text { dependen } \\
\text { Dismenore } \\
\text { pada saat } \\
\text { menstruasi }\end{array}$ & $\begin{array}{l}\text { Nyeri } \\
\text { menyerang/terjadi di perut } \\
\text { menjelang atau selama } \\
\text { haid, yang meliputi : } \\
\text { 1. Dismenore primer } \\
\text { 2. Dismenore sekunder }\end{array}$ & $\begin{array}{ll}\text { 1) } & \text { Terjadi (jika mengalami } \\
\text { nyeri pada daerah panggul } \\
\text { saat menstruasi) } \\
\text { 2) } \\
\text { Tidak terjadi } \\
\text { mengalami nyeri pada } \\
\text { daerah panggul saat } \\
\text { menstruasi) } \\
\text { (Kusmiran,2011) }\end{array}$ & $\begin{array}{l}\text { Nomina } \\
1\end{array}$ \\
\hline
\end{tabular}

\section{Populasi dan Instrumen pengumpulan data} (Kusmiran,2011)

Populasi dalam penelitian ini adalah remaja putri kelas XII kelas jurusan IPA dan Bahasa di MA Mamba'ul Ulum Awang-awang Mojosari kabupaten Mojokerto dengan jumlah populasi sebanyak 52 orang. Sedangkan instrumen yang digunakan untuk mengetahui terjadinya dismenore menggunakan kuesioner closed ended (dichotomy question) yaitu kuesioner yang berbentuk pilihan antara iya jika mengalami dismenore dan tidak jika tidak megalami dismenore.

\section{Teknik Analisa dan Pengolahan Data.}

\section{a. Teknik Analisa Data}

Dilakukan untuk mencari hubungan antara data variabel yaitu variabel bebas dan variabel terikat yang dilakukan dengan uji chisquare yaitu uji statistik yang 
digunakan untuk menguji signifikansi dua variabel yang mempunyai skala data ordinal dan nominal dengan bantuan program komputerisasi.

Pengambilan keputusan didasarkan pada besarnya nilai yaitu bila $\rho<0,05$ maka Ho ditolak, artinya ada tingkat stres dengan terjadinya dismenore pada remaja putri di MA Mamba'ul Ulum Awang-awang Mojosari kabupaten Mojokerto sedangkan bila $\rho>0,05$ maka Ho diterima, artinya tidak ada tingkat stres dengan terjadinya dismenore pada remaja putri di MA Mamba'ul Ulum Awang-awang Mojosari kabupaten Mojokerto.

Untuk interpretasi tabel menurut Nursalam (2003) adalah sebagai berikut:
a. $100 \%$ : Seluruhnya
b. $76 \%-99 \%$ : Hampir seluruhnya
c. $51 \%-75 \%$ : Sebagian besar
d. $50 \% \quad$ : Setengahnya
e. $25-49 \%$ : Hampir setengahnya
f. $1-25 \%$ : Sebagian kecil
g. $0 \% \quad$ : Tidak satupun

\section{b. Teknik Pengolahan Data}

Teknik pengolahan data merupakan kegiatan untuk merubah data mentah menjadi bentuk data yang ringkas dan disajikan serta dianalisis sebagai dasar pengambilan keputusan (Arikunto, 2010).

Dalam pengolahan data terdiri dari 4 langkah langkah, data yang terkumpul selanjutnya dilakukan pengolahan data melalui Editing (mengumpulkan semua kuesioner yang telah diisi oleh responden, Coding (mempermudah pengolahan, variabel penelitian diberi kode, dilakukan sebelum pengumpulan data dilaksanakan), Scoring (Penentuan jumlah skor sebelum di analisa) dan tabuling (penyajian matematis dalam bentuk tabel/daftar).

\section{HASIL PENELITIAN}

\section{Gambaran Umum Lokasi Penelitian.}

Madrasah Aliyah Mamba'ul Ulum terletak di Jl. Raya Mojosari Pacet No. 70 Dsn. Awang-awang Kec. Mojosari Kab. Mojokerto. Saat ini kepala sekolah Madrasah Aliyah Mamba'ul ulum adalah H. M. Alaika Fajri, S.H.I, MM. Kelas XII di Madrasah Aliyah Mamba'ul Ulum terdiri dari 4 kelas yaitu 1 kelas Program Ilmu Pengetahuan Alam (IPA), 2 kelas Program Ilmu Pengetahuan Sosial (IPS) dan 1 kelas Program Bahasa. Jumlah siswa kelas XII tahun ajaran 2011/2012 adalah 135 yang terdiri dari 26 siswa dan 109 siswi. Dari 109 siswi diambil 46 siswi yang memenuhi kriteria sampel yang telah ditentukan sebagai subjek penelitian.

2. Data Umum.

a. Karasteristik Responden.

Tabel 2 Distribusi frekuensi responden berdasarkan umur di Madrasah Aliyah Mamba'ul Ulum Awang-awang Mojosari Pada Tanggal 9-10 Mei 2014.

\begin{tabular}{|c|c|c|}
\hline Umur Responden & Frekuensi (f) & Persentase (\%) \\
\hline 15 tahun & 3 & 6,5 \\
16-17 tahun & 42 & 91,3 \\
$>17$ tahun & 1 & 2,2 \\
\hline Jumlah & 46 & 100 \\
\hline
\end{tabular}

Hasil penelitian menunjukkan bahwa hampir seluruhnya responden berumur 16-17 tahun yaitu sebanyak 42 respondn $(91,3 \%)$ 
3. Data Khusus.

a. Tingkat Stres

Tabel 3 Distribusi frekuensi responden berdasarkan tingkat stres di Madrasah Aliyah Mamba'ul Ulum Awang-awang Mojosari Pada Tanggal 9-10 Mei 2014.

\begin{tabular}{|l|c|c|}
\hline \multicolumn{1}{|c|}{ Tingkat Stres } & Frekuensi (f) & Persentase (\%) \\
\hline Normal & 18 & 39,1 \\
Stres Ringan & 12 & 26,1 \\
Stres Sedang & 11 & 23,9 \\
Stres Berat & 5 & 10,9 \\
Stres Sangat Berat & 0 & 0 \\
\hline \multicolumn{1}{|c|}{ Jumlah } & 46 & 100 \\
\hline
\end{tabular}

Hasil penelitian menunjukkan bahwa hampir setengahnya responden yang mengalami tidak stres atau normal yaitu sebanyak 18 responden $(39,1)$.

b. Kejadian Dismenore

Tabel 4 Distribusi frekuensi responden yang mengalami dismenore saat menstruasi di Madrasah Aliyah Mamba'ul Ulum Awang-awang Mojosari Pada Tanggal 9-10 Mei 2014.

\begin{tabular}{|l|c|c|}
\hline \multicolumn{1}{|c|}{ Dismenore } & Frekuensi (f) & Persentase (\%) \\
\hline Dismenore & 29 & 63,0 \\
Tidak dismenore & 17 & 37,0 \\
\hline \multicolumn{1}{|c|}{ Jumlah } & $\mathbf{4 6}$ & $\mathbf{1 0 0}$ \\
\hline
\end{tabular}

Hasil penelitian menunjukkan bahwa sebagian besar responden yang mengalami dismenore adalah sebanyak 29 responden $(63,0 \%)$.

c. Hubungan Tingkat Stres Dengan Terjadinya Dismenore

Tabel 5 Distribusi frekuensi hubungan tingkat stress dengan terjadinya dismenore pada remaja putri di Madrasah Aliyah Mamba'ul Ulum Awang-awang Mojosari Pada Tanggal 9-10 Mei 2014.

\begin{tabular}{|l|c|c|c|c|c|c|}
\hline \multirow{2}{*}{ Stres } & \multicolumn{4}{|c|}{ Dismenore Saat Menstruasi } & \multicolumn{2}{c|}{ Total } \\
\cline { 2 - 7 } & \multicolumn{2}{|c|}{ Dismenore } & \multicolumn{2}{c|}{$\begin{array}{c}\text { Tidak } \\
\text { Dismenore }\end{array}$} & \multicolumn{2}{c|}{} \\
\cline { 2 - 7 } & F & \% & F & \% & F & \% \\
\hline Normal & 7 & 15,2 & 11 & 23,9 & 18 & 39,1 \\
\hline Stres Ringan & 8 & 17,4 & 4 & 8,7 & 12 & 26,1 \\
\hline Stres Sedang & 9 & 19,6 & 2 & 4,3 & 11 & 23,9 \\
\hline Stres Berat & 5 & 10,9 & 0 & 0,0 & 5 & 10,9 \\
\hline Total & $\mathbf{2 9}$ & $\mathbf{6 3 , 0}$ & $\mathbf{1 7}$ & $\mathbf{3 7 , 0}$ & $\mathbf{4 6}$ & $\mathbf{1 0 0 , 0}$ \\
\hline
\end{tabular}

Hasil riset menunjukkan bahwa responden yang dismenore paling banyak mengalami stres sedang (19,6\%). Berdasarkan uji Chi Square diperoleh hasil perhitungan dengan nilai $X^{2}$ Hitung $=9,17$ sedangkan $X_{\text {tabel }}^{2}=7,815$ pada $\mathrm{df}=3$ dan $\rho=0,02$ dengan tingkat kemaknaan yang ditetapkan adalah pada $\alpha=0,05$. Oleh karena nilai $X_{\text {Hitung }}^{2}>X_{\text {tabel }}^{2}$ atau 9,17 > 7,815 maka H1 diterima dengan demikian ada hubungan tingkat stres dengan terjadinya dismenore pada remaja putri di Madrasah Aliyah Mamba'ul Ulum Awang-awang Mojosari kabupaten Mojokerto. 


\section{E. PEMBAHASAN}

1. Tingkat Stres Pada Remaja Putri.

Hasil penelitian menjelaskan bahwa hampir setengahnya responden yang mengalami tidak stres atau normal yaitu sebanyak 18 responden $(39,1)$. Berdasarkan gejala perilaku didapatkan bahwa sebagian kecil responden mengalami stres gejala perilaku yaitu sebanyak 5 responden $(10,9 \%)$.

Stres adalah suatu kondisi atau keadaan tubuh yang terganggu karena tekanan psikologis. Ada 3 macam tingkatan stres antara lain stres ringan, stres sedang dan stres berat. Faktor yang mempengaruhi stres adalah faktor lingkungan fisik : kebisingan dan suhu udara yang terlalu panas/dingin, faktor fisiologis : perubahan kondisi tubuh masa remaja misalnya haid serta reaksi tubuh terhadap ancaman dan perubahan lingkungan, faktor psikologis : ujian sekolah dan perceraian, dan masalah sehari-hari (Wulandari, 2010, Stuart dan Laraia 2005, Gunarya, 2008).

Hasil penelitian menunjukkan bahwa rata-rata responden mengalami stres ringan, hal ini disebabkan karena adanya tuntutan akademis yang dinilai terlalu berat sedangkan hasil ujian yang didapatkan tidak memenuhi standart nilai minimal, tugas yang menumpuk dan adanya tuntutan dari orang tua yang terlalu tinggi pada anak. Stres yang terjadi ditandai dengan anak menjadi marah karena hal-hal kecil atau sepeleh, cenderung bereaksi berlebihan pada situasi, mudah merasa kesal, merasa cemas, tidak sabaran, mudah tersinggung, mudah marah, sulit untuk beristirahat, dan sulit mentoleransi gangguan-gangguan terhadap hal yang sedang dilakukan.

Stres dilihat dari gejala psikologis menunjukkan bahwa sebagian besar responden mengalami stres gejala psikologis yaitu sebanyak 31 responden $(67,4 \%)$. Stres dilihat dari gejala fisiologis didapatkan bahwa sebagian kecil responden mengalami gejala stres fisiologis yaitu sebanyak 10 responden $(21,7 \%)$.

Menurut Hawari (2008) dan Wangsa (2010) Gejala fisiologis antara lain jantung berdebar-debar, muka pucat, gangguan gastrointestinal, gangguan pernafasan, gangguan pada kulit (timbul jerawat, kedua telapak tangan dan kaki berkeringat), sering buang air kecil, mulut dan bibir terasa kering, sakit kepala, sakit pada punggung bagian bawah, ketegangan otot serta gangguan tidur.

Sebagian kecil responden mengalami gejala stres fisiologis dilihat dari gejala fisiologisnya, hal ini ditunjukkan dengan responden yang mengalami jantung berdebar-debar, muka pucat pada saat dismenore.

\section{Dismenore Saat Menstruasi}

Hasil penelitian menunjukkan bahwa sebagian besar responden yang mengalami dismenore adalah sebanyak 29 responden (63,0\%). Hal ini disebabkan karena terjadinya dismenore primer pada responden yang di sebabkan oleh status gizi dan pola makan yang tidak teratur dan kurangnya olahraga atau malas, sehingga kebanyakan penderita dismenore adalah remaja atau wanita muda.

Berdasarkan klasifikasi dismenore primer didapatkan bahwa hampir setengahnya responden mengalami dismenore primer yaitu sebanyak 17 responden $(37,0 \%)$.

Faktor resiko dismenore primer adalah menstruasi pertama (menarche) di usia dini (kurang dari 12 tahun), wanita yang belum pernah melahirkan anak hidup (nullipara, darah menstruasi berjumlah banyak, atau masa menstruasi yang panjang, merokok, adanya riwayat nyeri menstruasi pada keluarga dan obesitas /kelebihan berat badan. (Proverawati, 2009).

Sebagian kecil repsonden mengalami dismenore primer, hal ini disebabkan salah satunya karena responden yang belum pernah melahirkan anak. Hal ini ditunjukkan dari anak yang mengatakan mengalami nyeri punggung bawah, sakit 
kepala dan kadang-kadang sapai jatuh pingsan. Berdasarkan klasifikasi didapatkan bahwa hampir setengahnya responden mengalami dismenore sekunder yaitu sebanyak 12 responden $(26,1 \%)$.

Menurut Laurel D. Edmundson (2006), dismenore sekunder memiliki ciri khas: onset pada usia sekitar 20-30 tahun, setelah siklus haid yang relatif tidak nyeri di masa lalu, infertilitas, darah haid yang banyak atau perdarahan tidak teratur, rasa nyeri saat berhubungan seks, keluar cairan yang tidak normal dari vagina, nyeri perut bawah atau pelvis selama waktu selain haid, nyeri yang tidak berkurang dengan terapi NSAID.

Sebagian kecil repsonden mengalami dismenore sekunder dikarenakan biasanya wanita yang mengalami dismenore sekunder adalah wanita yang berusia 20-30 tahun yang sudah menikah, oleh karena itu hanya sedikit dari responden yang mengalami dismenoder sekunder daripada primer.

\section{Hubungan Tingkat Sres Dengan Terjadinya Dismenore}

Penelitian menunjukkan bahwa responden yang dismenore paling banyak mengalami stres sedang (19,6 \%). Pada penelitian terdahulu tentang Pengaruh Stres Terhadap Tingkat Dismenore Primer Pada Siswi Kelas VIII SMP Negeri 1 KutorejoMojokerto tahun 2013 dengan jumlah sampel 86 responden di dapatkan hasil yaitu sebagian besar responden mengalami tingkat stres sedang sebanyak 53 responden $(61,6 \%)$ (Oktavina, 2013). Responden yang mengalami dismenore primer paling banyak mengalami gejala stres psikologis $(23,9 \%)$. Berdasarkan uji Chi Square diperoleh hasil perhitungan dengan nilai $X^{2}{ }_{\text {Hitung }}=9,17$ sedangkan $X_{\text {tabel }}^{2}=7,815$ pada $\mathrm{df}=3$ dan $\rho=0,02$ dengan tingkat kemaknaan yang ditetapkan adalah pada $\alpha=$ 0,05 . Oleh karena nilai $X_{\text {Hitung }}^{2}>X_{\text {tabel }}^{2}$ atau 9,17 > 7,815 maka H1 diterima dengan demikian ada hubungan tingkat stres dengan terjadinya dismenore pada remaja putri di Madrasah Aliyah Mamba'ul Ulum Awang-awang Mojosari kabupaten Mojokerto.

Salah satu faktor yang mempengaruhi kejadian dismenore saat menstruasi adalah stres. Stres adalah suatu kondisi yang disebabkan oleh transaksi antara individu dengan lingkungan yang menimbulkan persepsi jarak antara tuntutan yang berasal dari situasi dan sumber daya sistem biologis, psikologis, dan sosial (Suliswati, 2005).

Pada saat mengalami dismenore keadaan stres dapat menjadi faktor yang memperburuk dismenore, mereka menyatakan bahwa nyeri yang dirasakan pada saat dismenore primer semakin hebat ketika tingkat stres mereka semakin bertambah.

\section{F. PENUTUP}

\section{A. Simpulan}

Berdasarkan hasil penelitian maka dapat disimpulkan sebagai berikut :

1. Remaja putri di Madrasah Aliyah Mamba'ul Ulum Awang-awang Mojosari paling banyak tidak mengalami stres (normal)

2. Remaja putri di Madrsah Aliyah mamba'ul Ulum Awang-awang Mojosari kabupaten Mojokerto sebagian besar mengalami dismenore

3. Ada hubungan tingkat stres dengan terjadinya dismenore pada remaja putri di Madrasah Aliyah Mamba'ul Ulum Awang-awang Mojosari kabupaten Mojokerto.

\section{B. Saran}

1. Bagi Institusi Pendidikan

Lembaga memberikan pelatihan kepada Dosen untuk meningkatkan keterampilannya dalam memberikan bimbingan dan konseling pada siswi 
sehingga siswi dapat berupaya untuk mengantisipasi dan mengatasi stres dengan olahraga secara teratur dan istirahat yang cukup.

2. Bagi Instansi Kesehatan

Instansi dapat menjadikan data penelitian ini sebagai data dasar dalam sumber kepustakaan dan bacaan khususnya tentang Hubungan Tingkat Stres Dengan Terjadinya Dismenore .

3. Bagi Peneliti Selanjutnya

Peneliti dapat menggunakan data referensi penelitian ini sehingga peneliti selanjutnya dapat mengembangkan konsep atau melakukan penelitian tentang faktor-faktor yang mempengaruhi dismenore saat menstruasi dengan jumlah sampel yang lebih banyak, sehingga didapatkan hasil penelitian yang lebih lengkap.

\section{DAFTAR PUSTAKA}

Anurogo, D (2011). Cara Jitu Mengatasi Nyeri haid Yogyakarta: ANDI

Arikunto, Suharsini (2010). Prosedur Penelitian Pendekatan Praktek. Jakarta Rinekd Cipta

Baradero, M (2007). Gangguan Syistem Reproduksi dan Seksualitas. Jakarta: EGC

Hidayat, AAA (2010). Metologi Penelitian Kebidanan dan Teknik Analis Data. Jakarta Salemba Medika.

Jurnal Hubungan Tingkat Stres Dengan Dismenore, (2011).Surakarta : Universitas Sebelas Maret Surakarta.

Kusmiran, Eny (2011). Kesehatan Reproduksi Remaja dan Wanita. Jakarta: Salemba Medika. Manuaba, (2010). Penanganan Disminore (http: sehat.com (online), diakses 12 september 2010

Noviana (2008). Jurnal mekanisme koping mahasiswi keperawatan dalam menghadapi disminore. Vol. 08 No. 01

Nursalam, (2008). Konsep dan penerapan Metodologi Penelitian keperawatan Edisi 2 Jakarta: Salemba Medika

Pedoman Tugas Akhir Program Diploma III, (2013). Mojokerto: Politeknik Kesehatan Majapahit

Proverawati, A (2009)Menarche Menstruasi Pertama Penuh Makna. Yogyakarta: Nuha Medika

Riyanto, A (2011). Aplikasi Metodologi Penelitian Kesehatan Yogyakarta: Nuhamedika

Teguh, W (2010). Menghadapi Stress Dan Depresi. Yogyakarta : PT Suka Buku

Wulandari, A (2010). Cara Jitu mengatasi stres. Yogyakarta: ANDI. 